\title{
Inclusiveness in Service Delivery through Panchayati Raj Institutions in India with special reference to the State of Manipur
}

\author{
Mr.SonkhongamHaokip Dr.AnandaRajakumar. P \\ Professor and Research Supervisor, Department of Rural Development, The Gandhigram Rural Institute - \\ Deemed University. Gandhigram
}

\begin{abstract}
It has been widely argued that decentralized governance is an instrument for multifaceted development and it can ensure effective and equitable development at grassroots level (Maro 1990; Tuner 2000: 115; World Bank 2000:107). This is because, locally elected representatives know their small constituency better and are in advantageous position to provide better services according to their electorate's preferences. It is easier for the electorates to hold elected bodies accountable for their performance (Higgins 1992:3). In the present study, development refers to the progress achieved in decentralized governance per se and its effective, equitable and sustainable delivery of services to the satisfaction of the people. Effectiveness is understood as the ability of decentralized governance to produce results that meet the future needs of society while making the best use of resources at their disposal. Equity is defined as the ability of decentralized governance to distribute and to deliver services fairly as well as fair justice in the society to the satisfaction of disadvantaged groups, particularly the SCs, STs, women, including minorities and people below the poverty line. Sustainability means the ability of decentralized governance to generate and to maintain the development process for a longer period. This paper focuses on the effectiveness of service delivery by the panchayats in the State of Manipur. The paper is an extract from the Ph.D Thesis of Mr. SonkhongamHaokipentitled "Study of Issues of Social Inclusion and Exclusion in Manipur."
\end{abstract}

\section{INTRODUCTION}

Empowerment is something of a development "buzzword" (Cornwall, 2007), a broad concept that allows multiple interpretations and definitions, often reflecting the theoretical or ideological predisposition of their exponents. Ibrahim and Alkire (2007) have listed 32 different, but overlapping definitions of the word. This paper will use a definition based on Eyben (2011): "Empowerment happens when individuals and organized groups are able to imagine their world differently and to realize that vision by changing the relations of power that have kept them in poverty, restricted their voice and deprived them of their autonomy." The reasons for preferring this over other definitions is that it places the issue of empowerment squarely in the minds and hearts of poor and excluded individuals, seeking a proper balance between enhancing their own sense of agency and making the structural changes to institutions andpolicies that are needed for their emancipation. The definition also stresses the centrality of "power" to empowerment - a point that may seem obvious, but the word often slips out of definitions and leads to a more technical, less people- and powercentred discussion.The term development is multifarious and has different meanings to different scholars. The economic development concerns with production of output and related activities, particularly with the commercial and monetary aspects of these activities; the social perspective reflects concern with those aspects of development which are not directly or primarily concerned with production, output or material needs but with more general well-being of individuals or groups of people; the political perspective is concerned with the distribution of power between different groups or individuals, particularly the power to control or make decisions about the use of resources (Conyers and Hill 1984: 28-30). The two most common indicators of development are per capita income (national income divided by the size of the population) and the average annual growth of rate in the national income. However, experience suggests that the GDP growth is not having much impact on the life of the poor. Therefore, it is essential to understand development from the perspective of human well-being. Seers provides a list of eight important conditions for development like enough food, employment, equality, education, democracy, national independence, equal status for women, and sustainability (Seers 1979: 11-2). He also adds that if one or two of these conditions have been growing worse, then it is not development even if per capita income increases to higher level.Moreover, it has been widely argued that the means of development is not just to increase incomes, but to increase people's choices which may extend to standard education, good health, true democracy, cultural identity, social security, sustainability and many other areas of human well-being. Development must deal with the entire society, not just with economy, and people 
must be put at the center of the stage (Haq 1997). Also scholars have put forth another argument that the expansion of social opportunity is a key to development (Dreze and Sen 1997). Expansion of basic education, better health care, more effective land reforms and greater access to provisions of social security would enable the marginalized sections of society to lead a less restricted life and better use of markets.A governance process should aim at eliminating disparities and promote development. It should concern with mankind and should meet the basic needs of human beings, particularly the poor. It has been therefore, widely argued that decentralized governance is an instrument for this multifaceted development and it can ensure effective and equitable development at grassroots level (Maro 1990; Tuner 2000: 115; World Bank 2000:107). This is because, locally elected representatives know their small constituency better and are in advantageous position to provide better services according to their electorate's preferences. It is easier for the electorates to hold elected bodies accountable for their performance (Higgins 1992:3).

In the present study, development refers to the progress achieved in decentralized governance per se and its effective, equitable and sustainable delivery of services to the satisfaction of the people.Effectiveness is understood as the ability of decentralized governance to produce results that meet the future needs of society while making the best use of resources at their disposal. Equity is defined as the ability of decentralized governance to distribute and to deliver services fairly as well as fair justice in the society to the satisfaction of disadvantaged groups, particularly the SCs, STs, women, including minorities and people below the poverty line.Sustainability means the ability of decentralized governance to generate and to maintain the development process for a longer period. This paper focuses on the effectiveness of service delivery by the panchayats in the state of Manipur.

\section{MEASUREMENT PROCEDURE}

Data pertaining to development in terms of effectiveness was collected from the respondents through different area scale consisting of different indicators. It is however, recalled here that effectiveness was measured through the degree of satisfaction of individuals. Satisfaction in this context was measured in terms of 'score' obtained by individuals on the scale used for the present study. The satisfaction score depended on the nature of response (satisfied=1, dissatisfied=0) expressed by the respondents for different statements given in the scale.

\section{DIFFERENT VARIABLES AND MEASURING INDICATORS}

\section{Variables Indicators}

\section{Effectiveness:}

Poverty Availability of wages, rural housing, employment, ensuring social security, supply of goods, and supply of mini kits.

Education Accessibility of literature programmes, educational allowances and Equipment, Provision of schooling facilities, enrolment and retention in Schools.

Health Availability of Primary Health Care (PHC) system; availability of sub-centers, availability of Community Health Centre (CHC)

Services Rural energy, and drinking water, quality of food grains, Public Distribution System (PDS), rapid services or completion of work

Infrastructure Agricultural market, village link road, culvert/bridge, accessibility of electricity and irrigation

\section{RESULT OF ANALYSIS}

To assess the relationship between decentralized governance and development a composite score was calculated based on different indicators as mentioned above. Score "one" is given for "Satisfaction" and "Zero" for "dissatisfaction" for each indicator reported by respondent, adding scores for all indicators of a particular variable and divided the range of scores into three categories: low, medium and high. The figures obtained are presented in the tables that follow.

\section{HOUSEHOLDS}

It is recalled that 60 households from each Gram Panchayat under study were randomly drawn for interviews. For purpose of analysis the head of the households were grouped on the basis of sex, caste, occupation, land owned, education and income with a view to ascertain whether these socio-economic and demographic factors have had any impact on receiving benefits from gram panchayat. The per cent distribution of respondents for each indicator of a variable has been calculated for different sections and services. The figure thus obtained has been presented in table 1.1 for "effectiveness." 


\section{EFFECTIVENESS}

Housing is a bundle of expectations of the people based on their social upbringing and environmental conditions. Rural housing caters to the needs of shelter from the vagaries of weather and other personal privacy and protection and additional needs of village community like storage areas of grains, straw, fodder, agriculture and farm implements, space for the cattle which are part and parcel of the rural habitat. Other parameters like space for living, sleeping and cooking in view of the life-styles and habits of the village people and their family structure are also important aspects of rural habitation. Over the years housing has emerged as a social welfare programme and a number of schemes have been introduced since the Second Five Year Plan. The emphasis has always been on providing assistance for housing units of minimum acceptable standard to the rural poor. The Central Government had launched two major schemes viz. the allotment of house-site-cum construction assistance to rural landless workers including artisans and the Indira AwasYojana (IAY). The Panchayati Raj Institutions are the instruments at the grassroots level for implementing the various rural housing schemes meant for the less privileged households. Table 1.1 shows that about 50 percent of the respondents are satisfied with the implementation of rural housing schemes under IAY whereas the same percentage of the respondents is not satisfied with the implementation of the schemes. Overall, it was observed through the course of study that 64 percent of the households in the study panchayats have kutcha structures with plinth and wall made up of non-durable materials like mud and roofs are built of grass and thatched leaves. Further basic household facilities and amenities like drinking water, means of sanitary waste disposal, ventilators, lighting and electricity are mostly lacking in majority of the housing units. More than two-thirds of the respondents (77.5\%) are not satisfied with the availability of wages and employment. Though prosperity is positively related to agriculture, poverty is found to be higher in the panchayats studied. Open unemployment is declining but underemployment has been increasing. Educated unemployment is much higher that too among the females. Thought 99 percent of the labour force is engaged in agriculture the rate of agricultural growth is very low. It has also been observed that total number of days of employment is increasing at a lower rate compared to the total number of persons unemployed due to tremendous growth of labour force and the phenomenon of work sharing has started leading to shorter working days. Length of real work per person has actually come down. At the same time the amount of time taken to complete a given work has been increasing. The present phase of the implementation of MREGS (the local version of Mahatma Gandhi National Rural Employment Guarantee Act), which remains the only programme guaranteeing employment to the rural population in Manipur also provides mixed results. The programme proved to be a failure due to regular practices of 'non-payment of wages' (sometime even up to a year and half- in TellouChannaSeijang GP). As people lack interest, most of the works under MREGS have been given out to contractors. The employment tenure of this programme has also been rather short. The average employment provided by MREGS in a year was less than 30 days against the target of 100 days.Overall, it has been observed that there is surplus manpower in agriculture where their marginal productivity is near zero and the potential loss of output due to inefficient use of this powerful resource as well as frustration of youth job seekers being on the rise. In this aspect, the self-employment sector is a potential sector that needs to be augmented.

Table 1.1

Distribution of respondents by Effectiveness (Poverty alleviation Programme)

\begin{tabular}{|c|l|l|l|l|l|l|l|l|}
\hline \multirow{2}{*}{$\begin{array}{l}\text { Sl. } \\
\text { No. }\end{array}$} & \multirow{2}{*}{ Poverty eradication programmes } & \multicolumn{2}{|c|}{ Satisfied } & \multicolumn{2}{|c|}{ Dissatisfie } & \multicolumn{2}{|c|}{ Total } \\
\cline { 3 - 9 } & & $\mathbf{N}$ & $\mathbf{\%}$ & $\mathbf{N}$ & $\mathbf{\%}$ & $\mathbf{N}$ & $\%$ \\
\hline 1 & Rural housing & $\begin{array}{l}12 \\
0\end{array}$ & 50.0 & $\begin{array}{l}12 \\
0\end{array}$ & 50.0 & $\begin{array}{l}24 \\
0\end{array}$ & 100.0 \\
\hline 2 & Availability of wages and employment & 54 & 22.5 & $\begin{array}{l}18 \\
6\end{array}$ & 77.5 & $\begin{array}{l}24 \\
0\end{array}$ & 100.0 \\
\hline 3 & Ensuring social security & 66 & 27.5 & $\begin{array}{l}17 \\
4\end{array}$ & 72.5 & $\begin{array}{l}24 \\
0\end{array}$ & 100.0 \\
\hline
\end{tabular}

$N=$ Number of respondents

There is need to integrate the education programme with poverty alleviation programmes in such a manner that the dependency of the families on the earnings of the children is reduced and the child is free from the socio-economic hurdles. As regards the fulfillment of this requirement, creation of school facilities under various Central and State-sponsored schemes is of utmost importance. Table 1.2 shows that only a meager $(17.5 \%)$ of the respondents were satisfied with provision of schooling facilities in the village. The number of schools at primary as well as upper primary level (one school in HaraorouThangkam gram panchayat; two schools in LaiphamKhunnou gram panchayat; 2 schools in Sawombunggram panchayatand 1 school in TellouChannaSeijang gram panchayat) was not increased since 1990 in all the study panchayats and Anganwadis were not functioning whereas private schools have increased tremendously in nearby towns. There 
are no educational centres for non-enrolled and drop-out children who cannot afford to avail schooling in the formal system due to reasons of poverty. Apart from the establishment of crèches and Anganwadis for preschool children, the incentives like mid-day meal, scholarships, and uniforms are necessary to enable the unaffordable sections to send their children to school. However, as the same table shows, none of the 240 respondents interviewed were satisfied with accessibility of literature programmes, provision of educational loans and provisions of educational incentives like mid-day meal or educational equipment like scholarships and uniforms. While enrolment in schools scores satisfactory level for more than half $(57.5 \%)$ of the total respondents, enrolment of girls at the upper primary level is dropping down among the general category and Scheduled Caste groups in all the panchayats studied.

Table 1.2 Distribution of respondents by Effectiveness (Education)

\begin{tabular}{|c|l|c|c|c|c|c|c|}
\hline \multirow{2}{*}{ Sl. No. } & \multicolumn{2}{|c|}{ Education } & \multicolumn{2}{|c|}{ Satisfied } & \multicolumn{2}{|c|}{ Dissatisfie } & \multicolumn{2}{|c|}{ Total } \\
\cline { 3 - 9 } & & $\mathbf{N}$ & $\mathbf{\%}$ & $\mathbf{N}$ & $\mathbf{\%}$ & $\mathbf{N}$ & $\%$ \\
\hline 1 & $\begin{array}{l}\text { Accessibility of literature programmes } \\
\text { (Village libraries) }\end{array}$ & 0 & 0.00 & 240 & 100.0 & 240 & 100.0 \\
\hline 2 & Provision of educational loans & 0 & 0.00 & 240 & 100.0 & 240 & 100.0 \\
\hline 3 & $\begin{array}{l}\text { Provision of scholarships, uniforms, } \\
\text { mid-day meal etc. }\end{array}$ & 0 & 0.00 & 240 & 100.0 & 240 & 100.0 \\
\hline 4 & Provision of schooling facilities & 42 & 17.5 & 198 & 82.5 & 240 & 100.0 \\
\hline 5 & Enrolment in schools & 138 & 57.5 & 102 & 42.5 & 240 & 100.0 \\
\hline
\end{tabular}

$N=$ Number of respondents

Health and development are symbolically linked. The formal has long been regarded a priority for sustained development interventions. Indeed, a meaningful health system is one that holistically captures the essence of the socio-economic situation in which it has to work. While significant progress has been recorded in reduction of birth rates, and control of communicable diseases, the general health scenario in the study panchayats is however less than encouraging. As table 1.3 below shows, 90 percent of the respondents are dissatisfied with the quality of inputs and services of Primary Health Care system. Paradoxically, while the reach of the rural health services is considered limited as the State Government spend less than 10 percent of development budget on health, there have been problems of underutilization of the available services; disease and malnutrition, mortality rates of women and children continue to be high. Above all, public health planning and management is weak and unsustainable; training and manpower planning efforts are not encouraging, and community participation is unsatisfactory.

Table 1.3 Distribution of respondents by Effectiveness (Health)

\begin{tabular}{|c|l|c|c|c|c|c|c|}
\hline \multirow{2}{*}{$\begin{array}{l}\text { Sl. } \\
\text { No. }\end{array}$} & \multirow{2}{*}{ Health } & \multicolumn{2}{|c|}{ Satisfied } & \multicolumn{2}{c|}{ Dissatisfied } & \multicolumn{2}{c|}{ Total } \\
\cline { 3 - 8 } & $\mathbf{N}$ & $\mathbf{\%}$ & $\mathbf{N}$ & $\mathbf{\%}$ & $\mathbf{N}$ & $\mathbf{\%}$ \\
\hline 1 & Control of communicable diseases & 228 & 95.0 & 12 & 5.0 & 240 & 100.0 \\
\hline 2 & Primary Health Care (PHC) system & 24 & 10.0 & 216 & 90.0 & 240 & 100.0 \\
\hline 3 & Reduction of birth rates and death rates & 150 & 62.5 & 90 & 37.5 & 240 & 100.0 \\
\hline
\end{tabular}

$N=$ Number of respondents

The ultimate goal of rural development efforts is to improve the quality of life of the people in the rural areas. It has been realized that mere increase in income does not lead to improvement in quality of life. It is the availability and access to basic amenities and services of acceptable standards to the people in the rural settlements which largely determine the quality of life. In this regard, effective functioning of Public Distribution System (PDS) is considered utmost importance as its basic objective is to ensure that the essential articles of daily use are made available at reasonable prices to the public particularly, the vulnerable sections of society both in urban and rural areas. However, table 1.4 below shows a very discouraging picture of PDS functioning in the study panchayats. An overwhelming 100 per cent of the respondents interviewed were not satisfied with the functioning of PDS. One of the drawbacks of the PDS is that only a part of the food subsidy reaches the poor. In LaiphamKhunnou Gram Panchayat, 'Kerosene' is the only essential items distributed through PDS as fair price shops are not functioning. Another indispensable input in development is 'Energy'. As the economic pattern changes in the rural areas energy requirement also changes. Commercial energy cannot keep pace with the rapid rise in consumption. Therefore for sustainable development, there is a need for gradual shift towards renewable energy sources. However, table 1.4 shows that the score of satisfaction in energy is also 'Nil'. The energy requirement of the domestic sector especially for cooking and space heating/water heating is derived from bio-energy sources. There is a considerable concern about the degradation of soil and environment 
due to over exploitation of fuel wood resources on one hand and shift towards crop residue and dung cake on the other. There is also a gender dimension to the fuel crisis as women spend considerable time in collecting fuel and also in preparing the food. As regards the commercial energy use in the household sector which is extremely irregular, it is restricted to lighting. Even today the percentage of houses using kerosene for lighting is considerably large and is characterized by low conversion and luminous efficiency. Drinking water and sanitation are also integral to both the philosophy and practice of rural development. Water is life and sanitation is a way of life. Both are critical for leading a quality life. While the availability of safe and adequate drinking water as well as improved sanitation has a direct bearing on the working conditions and health of the people and their capacity for optimum production, an overwhelming majority $(92.5 \%)$ of the respondents expressed dissatisfaction with these two complex but interrelated components. The rural drinking water supply projects in Manipur are implemented through the Public Health Engineering Departments (PHEDs). It was found in the course of the present study that certain backward areas were not attended to by the PHEDs. These include three of the four panchayats studied. With no community tanks and hand pumps villagers in these three GPs depended on spring water/streams which normally dried up in summer. The concept of total environmental sanitation was also absent in all the study panchayats.

Table 1.4Distribution of respondents by Effectiveness (Services)

\begin{tabular}{|c|l|c|c|c|c|c|c|}
\hline \multirow{2}{*}{$\begin{array}{c}\text { Sl. } \\
\text { No. }\end{array}$} & \multicolumn{1}{|c|}{ Services } & \multicolumn{2}{c|}{ Satisfied } & \multicolumn{2}{c|}{ Dissatisfied } & \multicolumn{2}{c|}{ Total } \\
\cline { 3 - 8 } & & $\mathbf{N}$ & $\mathbf{\%}$ & $\mathbf{N}$ & $\mathbf{\%}$ & $\mathbf{N}$ & $\mathbf{\%}$ \\
\hline 1 & Public Distribution System & 0 & 0.00 & 240 & 100.0 & 240 & 100.0 \\
\hline 2 & Rural Energy & 0 & 0.00 & 240 & 100.0 & 240 & 100.0 \\
\hline 3 & Safe Drinking water and Sanitation & 18 & 7.5 & 222 & 92.5 & 240 & 100.0 \\
\hline 4 & Availability of Quality food grains & 6 & 2.5 & 234 & 97.5 & 240 & 100.0 \\
\hline
\end{tabular}

$N=$ Number of respondents

A key element in the process of agricultural development is the marketing infrastructure which affects the basic economic functions of production, distribution and consumption. Improved marketing infrastructure and appropriate organization of marketing are essential if full advantage is to be taken of favourable production opportunities. Table 1.5 shows that an overwhelming majority (97.5\%) of the respondents were dissatisfied with agricultural marketing development. The farmers fail to receive remunerative prices for their marketable surpluses due to lack of an effective regulated marketing system and support prices. Exploitation of farmers by middle men has been very common in the rural economy despite the existence of regulated markets at the district and sub-district level. Small and marginal farmers have been the worst victims of the unregulated marketing system manned by money lenders and private vendors. In spite of a rising trend in agricultural production, per hectare productivity, per capita income and a number of markets regulated, arrivals have not been increasing. The proportion of arrivals to production has shown a downward trend over a period. This means, the impact of marketing regulation has not created any significant impact on the rural marketing except for commercial crops. The creation of infrastructure like transportation is an essential prerequisite for the socioeconomic development of an area. In an ideal situation, storage and processing as well as educational and medical facilities should be easily accessible to people in all the villages. Similarly the transportation system should provide free and uninterrupted movement of people and goods. However, it has been observed in table 1.5 that an overwhelming majority $(97.5 \%)$ of the respondents was not satisfied with rural infrastructure. Of the 30 villages surveyed, only 9 villages with population of 1200 have been connected by all-weather motor able roads. Electrification is also one of the critical infrastructures in rural development which facilitates the development of productive sectors as well as various services. With regard to rural electrification, 87.5 percent of the respondents were not satisfied. There is shortage in power supply in all the villages surveyed.

Table 1.5 Distribution of respondents by Effectiveness (Infrastructure)

\begin{tabular}{|c|l|c|c|c|c|c|c|}
\hline \multirow{2}{*}{$\begin{array}{c}\text { Sl. } \\
\text { No. }\end{array}$} & \multicolumn{1}{|c|}{ Infrastructure } & \multicolumn{2}{|c|}{ Satisfied } & \multicolumn{2}{c|}{ Dissatisfied } & \multicolumn{2}{c|}{ Total } \\
\cline { 3 - 9 } & N & \% & N & \% & N & \% \\
\hline 1 & Agricultural market & 6 & 2.5 & 234 & 97.5 & 240 & 100.0 \\
\hline 2 & $\begin{array}{l}\text { Better roads/culvert/bridge/drainage } \\
\text { system }\end{array}$ & 6 & 2.5 & 234 & 97.5 & 240 & 100.0 \\
\hline 3 & Accessibility of electricity & 30 & 12.5 & 210 & 87.5 & 240 & 100.0 \\
\hline
\end{tabular}

$N=$ Number of respondents

\section{CONCLUSION}

From the long narratives in this study combining individual and group experiences as well as the analysis of data presented through tables 1.1 to 1.5 , it can be concluded safely that effective and inclusive 
service delivery through thepanchayats has not taken place in the study panchayats. The four gram panchayats under investigation have generally failed to realize the desired impact of effective delivery of services principally because of the following reasons:

First, the necessary devolution of functionaries, functions, and funds has not taken place. Secondly, people's participation in decentralized governance is largely low. Third, the gram sabha in its present set-up has a limited role to play (The point that the gram sabha is entrusted with a larger functional domain is blurred with its mistaken identity as a forum for the disbursement of state largesse). Fourth, the mechanisms of accountability, transparency are not up to the desirable level. Fifth, the creation/continuance of parallel bodies for planning and implementation of development schemes at the local level has hurt the functioning of the PRIs (There is a serious problem of overlap/substitution at both ZillaParishad as well as gram Panchayat levels).The creation and continuance of parallel bodies for planning and implementation of development schemes at the local level hashurt the functioning of the Panchayati Raj Institutions (PRIs). Indeed, the establishment of such parallel bodies in the early years of the newly established local bodies of self-governance has stunted the development of these institutions in several instances.Often these parallel bodies represented processes external to the constitutionally mandated role of the PRIs and enabled the bureaucracy and MPs/MLAs to override the authority of democratically elected members of PRIs. Finally, capacity building of the people, leaders and gram sabhas is extremely low.

Unwillingness of the State Government to give out power to the panchayats remains the most important factor responsible for such a dismal state of the panchayats. Gram Panchayats were virtually made as an agent of senior leaders of the ruling party.In addition to the excessive centralization and bureaucratization of thepanchayati raj system in the state, there was a disturbing phenomenon of elite capture of the panchayats. The dominance over and capture of village panchayats by the bureaucracy and the local elites had reduced the panchayats to arenas of contestation for the spoils of office.

Then there is the two and a half-decade long state and militant violence in the State, which has not only gravely affected the normal functioning of governments at the grass-roots level but also provided an alibi for public officials to not perform. Manipur with a population of 30,23,141 (2002 census) is perhaps, the state with the highest per capita "terrorist organization" not only in India but the whole world. Of the 28 militant organizations branded as "Terrorist" in India under POTA, ten are from the North-East region out of which again six are from Manipur. Fratricidal fighting among these different insurgent groups has not only gravely affected the normal functioning of governance both at the State and local levels but also seriously eroded the civil society space. In fact, militant violence has contributed largely towards the shrinking of the democratic space and in silencing the voice of the civil society. There is no scope for any democratic space in the very organizational structure and mode of functioning of the insurgent groups and the average citizen has nowhere to appeal to in case of insurgent violence.

The unresolved question of insurgency and economic stagnancy moves in a vicious circle. The economic stagnancy that impedes employment and income growth serves as fertile ground for fortifying and sustaining insurgency. On the other hand, the growing militancy and the subsequent growth of the underground terrorist economy, backed by the disruptive power of the militants, distort and inhibit the processes of growth of legitimate economic and developmental activities. The civil society along with a wide variety of economic activities that were integral to the lives of the people of Manipur have been 'criminalized', forcing otherwise law abiding citizens into a collusive relationship with militants within their areas of influence (be it the Meitei militant group, the Nagas or the Kukis). Moreover, militant groups gradually usurp a wide range of governmental functions, including the (albeit conditional) perfection of life and property, and the provision of 'justice' to local communities.

Added to the phenomenon of insurgency and economic stagnancy, numerous civil-society protests in the form of bands and strikes, partial or total at the slightest provocation, have become frequent phenomenon. Throw into these mixes the question of governability and we have the enduring challenge that the state of Manipur face today.

To complicate matters is the half-hearted and unsystematic arrangement of the system of selfgovernance in the state. Although small population is in question, two systems of local government are in operation in Manipur and that too sometimes in contravention of the broad theoretical premise that dictated the criteria. The two systems are: Autonomous District Council under the Manipur Hill Areas, District councils Act 1975, but not under the VI schedule of the Indian Constitution, and the Panchayati Raj Institutions as per the $73^{\text {rd }}$ Amendment of the Indian Constitution. 


\section{REFERENCES}

[1] Aiyer, Mani Shankar. 2002. "Panchayati Raj: The Way Forward." Economic and Political Weekly, XXXVII (31): 3293-97.

[2] Alsop, Ruth. 2004. "Local Organizations in India: Roles and Relationships." Draft Research Report. World Bank, Washington, DC.

[3] Alsop, Ruth, and Nina Heinson. 2005. "Measuring Empowerment in Practice: Structuring Analysis and Framing Indicators.” Policy Research Working Paper No. 3510. World Bank, Development Economics Research Group, Washington, DC.

[4] Aziz, Abdul. 1993. "Decentralized Planning: The Karnataka Experiment." Thousand Oaks/London: Sage Publications.

[5] Bandyopadhyay, D. 1996. “Administration, Decentralization and Good Governance.” Economic and Political Weekly, 31 (47): 3109-14.

[6] Bhattacharya, M. 2002. "Panchayati Raj in West Bengal: Democratic Decentralization or Democratic Centralism.” New Delhi: Manak Publication.

[7] Bhargava, B.S. and Rama Rao. 1978. "Indian Local Government: A Study." Calcutta: Minerva Associates (publications) Pvt. Ltd.

[8] Behar, Amitabh. 1999. "Initiatives for Decentralization of Governance in Madhya Pradesh." Economic and Political Weekly, 34 (46): 3242-44.

[9] BuchNirmala. 2004. "Let the Sun Shine on the Grassroots Too." In New Issues in Panchayati Raj. New Delhi: Concept Publishing Company.

[10] Chaturvedi, T.N. 1998. “Accountability: The Concept and its Significance.” In Raj, K. Nigam (ed.), Public Accountability in Indian Polity. New Delhi:D.C. Publication.

[11] Chaudhuri, S. 2007. "What Difference Does a Constitutional Amendment Make?" In Decentralization and Local Governance in Developing Countries: A Comparative Perspective. Oxford University Press.

[12] George Lutz and Wolf Linder. 2004. "Traditional Structures in Local Governance for Development." Bern: Switzerland.

[13] Institute of Social Science (ISS). 1994. "Decentralized Planning and Panchayati Raj.” New Delhi: ISS \& Concept Publishing Company.

[14] Kothari, Rajni. 1999. "Issues in Decentralized Governance." In S.N. Jha and P.C. Mathur (eds.), Decentralization and Local Politics. New Delhi: Sage Publications.

[15] Kumar, Girish. 2002. "ConstitutionalizingPanchayats: Responses from State Legislatures.” Occasional Paper No. 4, Centre de Sciences Humaines, New Delhi. 